\title{
ALGUMAS PROVOCAÇÕES SOBRE PÓS-HUMANISMO E EDUCAÇÃO*
}

\author{
SOME TASKS ABOUT \\ POST-HUMANISM AND EDUCATION
}

José Antônio Feitosa Apolinário**

RESUMO: O presente artigo objetiva refletir acerca do conceito de pós-humanismo, considerando o âmbito de desenvolvimento e consolidação da técnica no mundo contemporâneo, propondo algumas provocações sobre suas possíveis implicações a uma reconfiguração da esfera da educação, a qual de algum modo já se acha em curso. Para tanto, o trabalho se inicia com um breve exame histórico-conceitual do pós-humanismo, buscando analisá-lo com base em uma problematização filosófica da técnica, concluindo com um incipiente elenco de perspectivas sobre possíveis intersecções entre a condição pós-humana e o domínio educacional.

PALAVRAS-CHAVES: Pós-humanismo; Humanismo; Técnica; Educação; Ciborgue.

ABSTRACT: This article aims to reflect on the concept of posthumanism, considering the development and consolidation of technique in the contemporary world, proposing some provocations about its possible implications for a reconfiguration of the sphere of education, which in some way is already underway. To this end, the work begins with a brief historical-conceptual examination of posthumanism, seeking to analyze it based on a philosophical problematization of technique, concluding with an incipient cast of perspectives on possible intersections between the posthuman condition and the human being educational domain.

KEYWORDS: Posthumanism; Humanism; Technique; Education; Cyborg.

"O homem é uma corda, atada entre o animal e o além-do-homem - uma corda sobre um abismo" ". Essa célebre afirmação desferida por Nietzsche no prólogo de Assim falou Zaratustra poderia ser tomada como a sinalização com a qual o humano estaria sentenciado a deixar de ser? Consistiria numa espécie de enunciação do humano enquanto simples devir, duração, feixe de tempo, existência fadada à desaparição, e isto em nome de uma existência sobre-humana (Übermensch) que estaria para além dele mesmo? Indicaria uma contra-interpretação à interpretação antropológica dominante? Colocaria em xeque a visão do humano como único ser dotado de logos, inteligência abstrata, racionalidade? As discussões surgidas nas últimas décadas em torno das incontornáveis questões trazidas pelas biotecnologias, microeletrônica, nanotecnologia e outros

\footnotetext{
* O presente artigo é resultante de palestra proferida no II Encontro do Sertão Filosófico e Dia Mundial da Filosofia: Direitos Humanos e Educação no Contexto da Sociedade Tecnocrática, realizado no dia 07 de novembro de 2018, no Instituto Federal - Campus Sertão de Serra Talhada (IF-Sertão), Pernambuco, promovido pelo Grupo de Pesquisa Sertão Filosófico.

** Doutor em Filosofia pelo Programa Integrado de Doutorado em Filosofia UFPB/UFPE/UFRN. Professor Adjunto da Universidade Federal Rural de Pernambuco - Unidade Acadêmica de Serra Talhada (UFRPEUAST), e coordenador do grupo de pesquisa Grupo de Estudo em Politica, Educação e Ética (GEPEDE/UFRPE).

${ }^{1}$ NIETZSCHE, Friedrich. Assim falou Zaratustra. In: Obras incompletas. 2. ed. Tradução de Rubens Rodrigues Torres Filho. São Paulo: Abril Cultural, 1978. Coleção Os Pensadores. Prólogo, \4, p. 235.
} 
ramos tecnocientíficos estremecem ainda mais as bases já tão abaladas do ser humano, estremecimento que decerto tem na filosofia nietzschiana um expressivo preparo. Elas vêm forjando um campo temático denominado pós-bumanismo cuja amplitude vai de grupos políticoideológicos a literatas e acadêmicos.

É inequívoco que desde o final do século XX temos transformado imensamente nossa relação com os objetos técnicos, e que muitos de nós já não conseguem se perceber e ser no mundo sem os mesmos. Além disso, a própria sociedade tecnocrática e seu mundo administrado pelas tecnociências cresceu debaixo de nossos narizes, inflou-se de tal maneira que nela já nos achamos há muito submersos. Nossa época é, entre outros fenômenos, a época da manipulação genética, da realidade virtual, da cibercultura, das inteligências artificiais, das nanotecnologias, da medicina restaurativa, da pulverização do uso de gadgets, do controle hipertrófico de informação. No mínimo, pode-se inferir que a experiência do humano atual é a de uma tensa ressignificação do próprio estatuto filosófico, científico e religioso do que significa ser humano. Por tal razão, o horizonte pós-humano parece reivindicar a questão sobre o ultrapassamento do humano pelo próprio humano como sua questão basilar, posicionando assim o problema e os impasses de uma exequível ‘superação' da condição humana até então experienciada.

Compreendendo esse horizonte, o artigo em voga objetiva refletir sobre alguns aspectos condizentes ao pós-humanismo desde o âmbito de desenvolvimento e firmação da técnica no cenário contemporâneo, arriscando levantar algumas provocações em torno de suas possíveis implicações a uma reconfiguração da esfera da educação, a qual de algum modo já se acha em curso. O itinerário ora proposto se inicia com um breve exame histórico-conceitual do pós-humanismo, buscando em seguida compreendê-lo à luz de uma problematização filosófica da técnica, ultimando com um incipiente elenco de perspectivas sobre possíveis intersecções entre a condição póshumana e o domínio educacional. A hipótese básica é a de que um determinado entendimento do pós-humano é em certa medida parte do cotidiano escolar em razão do uso sociocultural e pedagógico de tecnologias de informação, e de uma demanda curricular que ao fim e ao cabo pressiona professores, gestores e os próprios estudantes quando a problemática pós-humana se impõe como conjunto temático necessário à compreensão das mudanças transcorrentes em nosso tempo.

Tomando o referido caminho, uma primeira chave interpretativa ao exame em torno de um sentido plausível do pós-humano pode ser encontrada, conforme supomos, na 'passagem' da ficção científica - na literatura, no cinema, na cultura pop - para o cotidiano do século XXI. Aparentemente simplista, a compreensão dessa espécie de trânsito figura como significativa porque com a presença cada vez mais massiva dos objetos técnicos no modo de organização da vida 
humana a contar das primeiras dinâmicas da indústria até a hoje disseminada 'quarta revolução industrial', cujo suporte sociocultural e econômico é a 'sociedade em rede'3, vivifica-se aquilo que apenas a arte e seu reconhecido potencial antecipatório foi capaz de inventar. O que parece colocar Mary Shelley, H. G. Wells, E. M. Foster, Isaac Asimov, Fritz Lang, Stanisław Lem, Aldous Huxley, Alfred Elton van Vogt, Arthur Clarke, Daniel F. Galouye em um mesmo horizonte é a perspicácia em imaginar um futuro humano poeticamente possível, indicado em larga medida pelo contexto histórico no qual o desenvolvimento tecnocientífico alinhado à indústria começava a ganhar musculatura.

Sem superestimar aspectos hiperbólicos e distópicos de algumas narrativas de ficção científica, supomos que uma de suas nítidas características reside no poder de ressaltar a presença incômoda, estranhada ou relativamente naturalizada dos objetos técnicos em meio à existência humana, com particular ênfase nos objetos maquínicos e autômatos, próprios da fase de desenvolvimento da técnica desde então vigente ${ }^{4}$. Tal presença se espraiará em meados do século XX com a cultura de massas - mormente com os conteúdos televisivos, cinematográficos e a cultura pop - uma vez que o modo geral de organização da vida nas sociedades industrializadas (e em vias de industrializarse) estrutura-se intersticial e definitivamente mediante tecnologias. Incorporadas às mais distintas ações cotidianas, partícipes de incontáveis lógicas (do trabalho à educação, do lazer ao mercado, da saúde à comunicação,...), máquinas e autômatos figuram como objetos técnicos por excelência da sociedade tecnocrática.

$\mathrm{Na}$ dita sociedade, o estar em meio aos objetos técnicos tornou-se então simbiótico sob a perspectiva de dois momentos sucessivos e com elevado grau de simultaneidade, configurados, de acordo com nossa interpretação, pela distinção entre as vivências de um nós e os objetos técnicos, e um os objetos técnicos em nós. Ambas são vivências que se atravessam e se confundem historicamente. A primeira diz respeito ao fato de coabitarmos um mundo cujo em torno é propriamente técnico; condiz a um 'habitar o mundo' na condição de mundo tecnicamente administrado e conformado por um sem-número de tecnologias com as quais nos relacionamos de modo umbilical desde que somos-estamos nele, em uma circunstância que de alguma forma naturalizamos. A segunda, a mais recente na história da técnica, caracteriza-se pelas diversas modalidades de fusão entre seres humanos e tecnologias, inaugurando o período no qual os objetos técnicos não estão mais unicamente à nossa volta, mas passaram a estar em nós, e nós passamos à condição de

\footnotetext{
${ }^{2}$ Cf. SCHWAB, Klaus. A quarta revolução industrial. São Paulo: Edipro, 2016.

${ }^{3}$ Cf. CASTELLS, Manuel. A sociedade em rede. 11. ed. São Paulo: Paz e Terra, 2008.

${ }^{4}$ Acerca desse potencial antecipatório das narrativas de ficção científica, Peter Sloterdijk entende ser legítima a tese do filósofo alemão Gotthard Günther segundo a qual haveria uma tarefa filosófica inerente à literatura de ficção científica, ao afirmar que este "defendeu, com boas razões, uma visão do gênero novelístico de ficção científica como um laboratório da filosofia da época tecnológica" (SLOTERDIJK, Peter. Has de cambiar tu vida. Sobre antropotécnica. Valencia: Editorial Pre-Textos, 2012, p. 135).
} 
corporeidades abertas, corpos disponíveis à efetuação da experiência que vai da passagem, da permanência e de uma co-constituição, um ser-com objetos técnicos.

Os processos cada vez mais comuns de concretização do que aqui chamamos objetos técnicos em nós - um vasto repertório de fármacos, acoplamentos, próteses, microchips, extensões, hardwares, substitutivos, aparelhos, salientando igualmente as intervenções e os procedimentos técnicos neste rol de possibilidades - acabam contribuindo para o engendramento de um campo de questões ontológicas, éticas, culturais, jurídicas, e outras, cujas circunscrições ainda não conseguem ser delimitadas. A pergunta nodal inscreve-se na tese conforme a qual a tecnologia colocou de maneira cabal o problema em torno de nossa autocompreensão como seres humanos ${ }^{5}$. Quando as tecnologias se tornam parte constitutiva da bios humana ou quando, em alguma medida, replicam a bios humana sob a condição de máquina autônoma, inteligência artificial, o que passa a estar em jogo, no limite, é o fato de que aquele tradicional e dominante conjunto de elementos que nos predicavam a condição de humanos começa a liquefazer-se. Ademais, o conhecimento científico parece estatuir precisamente o que apenas a arte enquanto ficção científica fora capaz de antecipar: o problema acerca do pós-humano.

Com efeito, a discussão sobre o pós-humanismo precisa levar em conta uma prévia percepção sobre o humanismo. Muito além de posicionar-se como uma corrente filosófica e pedagógica, e de ter um contexto específico de surgimento (a Humanitas latina), o humanismo se estabelece enquanto tendência geral de compreensão do lugar do humano no mundo como dotado de centralidade com relação aos outros seres. Ser cuja verdadeira natureza residiria no desenvolvimento de suas potências intelectuais e morais intrínsecas, concomitante ao arrefecimento e superação do elemento animal propriamente não-humano. Portanto, em linhas gerais, enquanto discurso filosófico, o humanismo propõe haver um 'humano' que precisa ser haurido do 'ser humano', tarefa assegurada pela educação, filosofia, religião, e mais tarde pela ciência, na condição de instrumentos do espírito.

O reconhecimento da dignidade e a convicção na capacidade oferecida pela educabilidade humana de livrar-se do condicionamento dos instintos animais, posto que tais instintos seriam responsáveis pelos desvios impulsivos, paixões degradantes, e, em última instância, pela violência e destrutividade das ações humanas (defesa de um 'mal' vinculado à parte animal do ente humano), marcam de modo fundamental o humanismo como tendência e como projeto. Contudo, tal projeto é conduzido ao patíbulo crítico do pensamento filosófico contemporâneo, de tal sorte que vários acontecimentos históricos, sociais e culturais do século XX terminam por colocá-lo em uma situação de profundo descrédito: além de ser acusado de não realizar seu propósito como projeto

${ }^{5}$ Cf. HABERMAS, Jürgen. O futuro da natureza humana. São Paulo: Martins Fontes, 2010. 
e de fundar-se numa antropologia filosófica equivocada, a lógica humanista é tida como uma das lógicas subjacentes à fomentação e estruturação das formas de barbárie historicamente vividas no referido século.

Por esse meandro, é no mínimo tratado como um programa cuja vigência dar-se-ia unicamente no limbo da contrafactualidade, e no máximo, como um propulsor das pulsões destrutivas apinhadas ao humano - para dizer psicanaliticamente - sendo, por conseguinte, o maior antagonista de si mesmo. Emerge desde então uma crise do humanismo. Mas será este o horizonte possibilitador do engendramento do discurso pós-humanista? Poder-se-ia afirmar que este surge em franca correspondência com a liquefação daquele? Ou não estaríamos presenciando a eclosão de um discurso que, embora se posicione como 'pós' humanista (guardando aqui o caldeirão semântico encerrado nessa terminologia), seria por outras vias responsável pelo coroamento do programa humanista?

Não obstante esteja concentrada em distintos grupos artísticos, religiosos, políticos, acadêmicos, e seja constituída por diversas vertentes, a concepção de pós-humanismo ou transhumanismo denota uma silhueta minimamente comum em termos teóricos e programáticos. Entre tais vertentes há moderadas como a extropiana, outras mais radicais como a transtropiana e a prometeísta, outras como a raeliana de viés religioso, e mais singularmente a instituição $A W$ orld Transhumanistic Association que se apresenta na contramão das demais vertentes por seu perfil acadêmico comprometido com o esclarecimento e a pesquisa em torno do tema ${ }^{6}$. Para além dos espalhafatosos elementos oriundos de matrizes políticas ultraconservadoras, das leituras muitíssimo apressadas em torno de uma suposta herança nietzschiana ${ }^{7}$, e dos delírios fictícios que entorpecem os discursos, há diapasões interpretativos e atitudinais que permitem, segundo entendo, elencar aspectos basilares a uma ideia geral de pós-humanismo.

Conforme mencionamos acima, do ponto de vista histórico parece legítimo entendê-lo primeiramente como um movimento e, portanto, como dinâmica que envolve um determinado número de pessoas orientadas para uma direção comum (ideia, causa, finalidade), que, todavia, é selado por uma variedade de tendências não necessariamente comunicáveis e âmbitos específicos de ação (estético, econômico, político, acadêmico). Dessa perspectiva, poder-se-ia assegurar, como faz Francisco Rüdiger, que "o pós-humanismo é um movimento desarticulado de agrupamentos, concepções, filosofias e estilos de vida que, visto genericamente, ambiciona controlar o mundo e

\footnotetext{
${ }^{6}$ Sobre as mencionadas vertentes do pós-humanismo no final do século XX, cf. RÜDIGER, Francisco. Cibercultura e pós-humanismo: exercícios de arqueologia e criticismo. Porto Alegre: EDIPUCRS, 2008. p. 141-158.

${ }^{7}$ Sobre a validade da hipótese de que o pós-humanismo ou o transhumanismo seria herdeiro do pensamento de Nietzsche cabe a nosso ver confrontá-la com a reflexão sobre o niilismo, o sentido trágico da existência e com uma interpretação mais aprofundada do Übermensch, entre outros tópicos atinentes à sua filosofia. Nessa perspectiva, vejase: TUNCEL, Yunus (Org.). Nietzsche and transhumanism: precursor or enemy. New Castle: Cambridge Scholars Publishing, 2017. Naturalmente, essa tarefa foge do escopo do presente artigo.
} 
transcender a condição humana” (RÜDIGER, 2008, p. 155). Não obstante as diferenças apontadas, cabe ressaltar as duas motivações gerais ambicionadas pelo pós-humanismo sob a óptica aqui exposta: o 'controle sobre o mundo' e a 'transcendência da condição humana'.

Aparentemente hiperbólicas, tais motivações parecem sintetizar aspectos que permeiam o universo ideológico pós-humanista, dentre os quais salientamos: a crença na capacidade redentora da tecnologia; o vivente humano enquanto algo 'produzido' e não como algo ‘dado', e, portanto, como passível de experimentos, devendo assim estar aberto a tais experimentos; o corpo-organismo é considerado um interdito (imperfeito, limitado), mas ao mesmo tempo, campo apto a transformações, alterações, intervenções, upgrades, acoplamentos, hibridizações; a 'maquinização' e/ou 'digitalização’ do humano impõe-se como possibilidade de superação de condições biológicas naturais limitantes; o ser humano é compreendido a partir de sua mente (na condição de processadora de informação e ela mesma informação); inversão e positivação moral do sentido religioso-apocalíptico da condição humana; hipertrofia da cibernética mediante propensão ao controle total dos processos biológicos e culturais. No limite, haveria uma inundante 'conjuntura pós-humana' cuja meta, seja qual for o conteúdo mesmo dessa meta, consiste em ultrapassar a configuração histórica e biológica do humano atual. Conforme assegura Rüdiger,

as tecnologias criadoras de realidade virtual, a engenharia genética, a medicina restauradora, as operações de mudança de sexo, as próteses de todos os tipos, para não falar da exploração de outros mundos, insinuam que já está em curso um processo bastante perturbador e profundo de modificação da condição humana (RÜDIGER, 2008, p. 143).

Poder-se-ia então, a título de conjetura, pensar o pós-humanismo sob dois vieses: 1) como um movimento de interpretações plurívocas iniciado historicamente no derradeiro quartel do século XX, que reúne em sua órbita - com maior ou menor ênfase - a valorização da cibernética e da tecnologia na direção do destino humano; e 2) como um processo em grande parte incontornável, definido por uma reconfiguração programática do humano, a qual já se presentifica pelos mais diferentes meios técnicos e tecnocientíficos disponíveis e em andamento em nosso tempo. Exemplos deste último rasgo não faltam: um deles é o campo dos métodos biotecnológicos de edição genética. Hoje já é possível realizar modificações pela edição de genes de qualquer ser vivo, como ocorre com o sistema CRISPR/Cas (Clustered Regularly Interspaced Short Palindromic Repeats), de tal modo que o DNA passa a ser manipulável num grau digno de impressionar. O CRISPR/Cas enquanto técnica que permite controlar os mecanismos de defesa das bactérias do $\mathrm{DNA}^{8}$, ilustra o

\footnotetext{
${ }^{8}$ Em torno do método CRISPR-Cas veja-se: JINEK, Martin.; CHYLINSKI, Krzysztof.; FONFARA, Ines.; $\underline{\text { HAUER, }}$ Michael.; DOUDNA, Jennifer. A.; CHARPENTIER, Emmanuelle. A programmable dual-RNA-guided DNA endonuclease in adaptive bacterial immunity. Science. Associação Americana para o Avanço da Ciência, v. 337, $n^{\circ}$ 6096, 2012. Bem como: DOUDNA, Jennifer. A.; CHARPENTIER, Emmanuelle. The new frontier of genome engineering with CRISPR-Cas9. Science. Associação Americana para o Avanço da Ciência, v. 346, nº 6213, 2014.
} 
gigantesco alcance a que pode chegar o domínio cibernético sobre a vida na totalidade, e a vida humana em particular, carreando incontáveis questões ontológicas, éticas e jurídicas, como adverte a quase três décadas o filósofo Francis Fukuyama?.

Disto se segue que o pós-humano só veio a ser como movimento e processo em razão do desenvolvimento hipertrófico da técnica. Esta pode ser concebida, nos trilhos da ontologia da técnica proposta pelo filósofo José Ortega y Gasset em Meditação da Técnica, de duas maneiras: inicialmente como "reação enérgica contra a natureza ou circunstância que leva a criar entre estas e o homem uma nova natureza posta sobre aquela, uma sobrenatureza" (ORTEGA Y GASSET, 2009, p. 32); e, em segundo lugar, técnica consiste no "esforço para poupar esforço" (ORTEGA Y GASSET, 2009, p. 35). Por conseguinte, para Ortega y Gasset, técnica é em primeiro lugar uma reação que se confunde com a filo e a ontogênese humana, condizendo ao ato propriamente humano de engendramento de cultura em função da resistência que opõe às adversidades das circunstâncias mundanas, naturais, existenciais, bem como em face das possibilidades ofertadas ao humano por tais circunstâncias; sendo, em seguida, interpretada como esforço cujo telos intrínseco e quase tautológico é diminuir esforço, poupar o desgaste, reduzir a carência, em direção à produção do supérfluo (bem-estar) ${ }^{10}$.

Dos trilhos orteguianos pode-se inferir a defesa de uma consubstanciação entre técnica e condição humana compreendida nos termos de uma antropogênese. Enquanto viventes cuja dinâmica de desenvolvimento é imemorial, tornamo-nos humanos criando-nos a nós mesmos, forjando-nos mediante a edificação de um horizonte técnico o qual concomitantemente alargamos de forma exponencial ao abrigo da cultura. Isto não significa afirmar de modo simples que somos 'animais técnicos' - enxergando a técnica como mera capacidade, habilidade ou 'saber-fazer' ligado a techné grega -, mas, muito além disso, implica pensar-nos na condição de entes para os quais existir (ser, viver) pressupõe um horizonte técnico ao mesmo tempo construído e constitutivo. Desse ângulo, a história humana é a história das múltiplas (sucessivas e simultâneas) possibilidades de ser enquanto autoproduções que cada indivíduo e grupo humano fez, faz e continuará a fazer dele mesmo. É nesse sentido que Ortega y Gasset concebe viver como produzir (ORTEGA Y GASSET, 2009). Segundo Alberto Cupani, na filosofia da técnica apresentada pelo filósofo espanhol,

\footnotetext{
${ }^{9}$ Cf. Cf. FUKUYAMA, Francis. Nosso futuro pós-humano: consequências da revolução da biotecnologia. Rio de Janeiro: Rocco, 2003. Sobre o dilema ético que se apresenta em face das possibilidades abertas ao humano pela edição genética, assinala Salvador D. Bergel: “a manipulação genética tem um sustento moral se é utilizada para prevenir ou curar patologias, para além das dificuldades que possa significar o ato de defini-las; não para satisfazer desejos ou caprichos dos homens ainda quando isso for científica ou tecnicamente possível” (p. BERGEL, 2017, p. 459).

${ }^{10}$ Sobre a ideia orteguiana de esforço no contexto de Meditação da Técnica, Jérfeson Assunção considera a cultura como sendo esse esforço, abrangendo tanto o produzir como o produzido: “para Ortega, a cultura é um esforço natatório que nos possibilita flutuar num mar de absurdo. Esforço coletivo e individual para tentar dar conta de um mundo (uma vida) que nos foi dado mas não foi dado pronto", arrematando que "a cultura é o resultado do pesado esforço de muitos indivíduos e suas interações” (ASSUMÇÃO, 2012, p. 17).
} 
o homem não é uma coisa, 'mas uma pretensão de ser'. O homem (trate-se do indivíduo, de um povo ou de uma época) é um programa de vida em uma determinada circunstância ou 'mundo' ou 'Natureza' [...] a vida é, para o homem, não algo já feito ou dado, mas um constante problema. O homem deve literalmente fazer a sua vida, deve autofabricar-se (CUPANI, 2016, p. 34. Grifo do autor).

Conforme percebo, Ortega assume uma concepção de técnica higienizada da ideia de progresso e de conteúdos escatológicos, colocando-se fora de quaisquer lógicas vinculantes entre desenvolvimento técnico e atingimento de um patamar axiológico supostamente realizador do destino humano. A técnica (ou tecnologia ${ }^{11}$ ) não tem para ele qualquer compromisso que não seja, no limite, a produção do supérfluo em cada caso em que vem a ser como reação engendrante de possibilidades ante a circunstância.

Essa ligeira passagem pelo pensamento orteguiano nos faculta problematizar as duas motivações gerais que ao fim e ao cabo resumiriam o ideário pós-humanista, quais sejam, o controle sobre a vida e o ultrapassamento da condição humana. Ora, se adotarmos a posição ontológicoexistencial do humano como ser essencialmente técnico e, portanto, como ente cuja existência estaria sempre por se fazer, não resultaria então paradoxal sustentar uma transcendência técnica do humano? Não seria o desejo de uma pretensa superação do humano (mormente o corpo) pela técnica algo inconcebível, uma vez que o que se denomina em geral pós-humano não passaria de um arranjo histórica e temporalmente autofabricado do próprio humano? Destarte, não estaria o pós-humano fadado a continuar humano e o discurso pós-humanista não acabaria por 'se tornar uma fábula’?!

Não se trata de uma questão simplória: se o controle sobre a circunstância, para falar como Ortega, ganha tons mais sofisticados por intermédio da cibernética (controle este entendido enquanto capacidade técnica de manipulação e domínio da natureza e da vida, o que não significa referir-se a um controle in totum), a ideia de transcendência do humano, principalmente como abandono de uma 'corporeidade limitadora', aparenta dirigir-se à condição humana atual, posto que o que se busca superar é uma determinada ideia de ser humano, permutando-a por outra, e não uma superação do humano na totalidade. Isto porquanto, conforme a tese orteguiana, o humano não pode ser subtraído à técnica e nem vice-versa, pois estão ontologicamente co-implicados. Além disso, seguindo esse viés interpretativo, divido com outros intérpretes ${ }^{12}$ a hipótese de que o póshumanismo permanece umbilicalmente ligado ao humanismo, tanto em razão dessa

\footnotetext{
${ }^{11}$ Sobre possíveis distinções entre técnica e tecnologia, veja-se CUPANI, Alberto. Filosofia da tecnologia: um convite. 3. ed. Florianópolis: Editora da UFSC, 2016.93-99.

12 Cf. ROMANDINI, Fabián Ludueña. A comunidade dos espectros. I. Antropotecnia. Desterro, Florianópolis: Cultura e barbárie, 2012. p. 223-241; bem como SLOTERDIJK, Peter. Regras para o parque humano. Uma resposta à carta de Heidegger sobre o humanismo. São Paulo: Estação Liberdade, 2000. p. 44-47.
} 
impossibilidade de desvinculação entre humano e técnica quanto, e de modo mais visceral, pelo fato de comungar do mesmo ideal redentorista e teológico daquele ${ }^{13}$.

Nesse fio condutor, via de regra, o humanismo figura como discurso filosófico-educativo cuja ideia central é a de que nos tornamos humanos na medida em que transcendemos nossa animalidade, isto mediante o cultivo do espírito ou, nos termos de Peter Sloterdijk (2000), através de programas antropotécnicos educacionais, religiosos e morais. Com efeito, a lógica humanista do ultrapassamento do animal no humano estatui uma sociogênese sob a forma de negação: paixões, emoções, impulsos, numa única palavra, corpo, todos violenta ou sutilmente negados, adaptados, amainados, adestrados, disciplinados, como conditio em direção à 'humanidade'. Essa assepsia da animalitas dá-se então, em simultâneo, na razão direta da supervalorização da razão (e suas expressões cognatas: pensamento, consciência, inteligência, linguagem) enquanto indicativo de 'humanidade' e fundamento da ideia de sujeito moderno ${ }^{14}$.

Contudo, o conceito de sujeito apinhado à ideia de humano cimentada desde o âmago do humanismo tombou, perdeu força explicativa, tornando-se assim impotente. Segundo Cecília de Sousa Neves,

esta impotência justifica a proposta de superação do humano que aponta não para um conceito reformulado do ser humano, mas para outro conceito relacionado a um novo modo de existência substancialmente diferente, designado como pós-humanidade. Nesse registro, alertamos para o fato de que objetiva-se com a noção de pós-humanidade a construção de um entendimento acerca do fenômeno humano que esteja sintonizado com o desenvolvimento sem precedentes da técnica e seus imperativos (NEVES, 2015, p. 259).

Embora assuma a percepção de que a ideia de pós-humano, segundo os seus entusiastas, não condiz a uma 'reformulação' conceitual do ser humano, mas a um modo de existência substancial (à guisa de Aristóteles) e radicalmente distinto da ideia de humano herdada do humanismo, reconhecendo o motor ontológico historicamente ímpar da técnica nessa orquestração ${ }^{15}$, questiono como poderia tal proposta fazer o humano 'saltar sobre sua própria

\footnotetext{
${ }^{13}$ Quanto ao conteúdo dos textos das várias correntes pós-humanistas, escreve Dominique Lecourt: “um aspecto de todos esses textos científicos, tecnológicos ou literários chama a atenção: o seu vocabulário religioso e a presença de temas teológicos insistentemente agitados"; e continua o autor: "pode-se falar a respeito disso de uma 'religião da tecnologia', em um sentido que não e absolutamente metafórico" (LECOURT, 2005, p. 64).

${ }^{14}$ Como afirma Tomaz Tadeu, "foi a imagem de um sujeito pensante, racional e reflexivo, considerado como a origem e o centro do pensamento e da ação, que esteve subjacente, até recentemente, às principais teorias sociais e políticas ocidentais. Esse "sujeito" é, na verdade, o fundamento da ideia moderna e liberal de democracia. É "ele", ainda, que está no centro da própria ideia moderna de educação" (TADEU, 2009, p. 14).

${ }^{15}$ Mencionando o filósofo alemão Gunther Anders, Adauto Novaes chama atenção para essa primazia da técnica em nosso tempo ao salientar que o humano é por ela exonerado do cargo de sujeito da história: "é certo que vivemos entre dois mundos, um que ainda não acabou inteiramente e outro que ainda não começou inteiramente. Nessa ambivalência, antes éramos adeptos do pensamento humanista, mesmo que Michel Foucault já falasse do fim do humanismo. Não imaginávamos o surgimento do que se convencionou chamar de pós-humano. Para nós o homem ainda era o sujeito da história. Não ouvíamos com atenção o que o filósofo Gunther Anders dizia sobre a obsolescência do homem. Mas suas hipóteses iam muito além: a técnica tornou-se o sujeito da história, 'o que é confirmado de maneira espantosa pelo fato
} 
sombra’? Erradicar integralmente o humano do pós-humano, constitui-se mesmo como uma superação no sentido simples da expressão? Até que ponto então o pós-humanismo compreende algo deveras distinto do humanismo? Não conservaria intacto em seu ideário o conjunto de aspirações humanistas?

Duas perspectivas me endereçam a uma resposta afirmativa: em primeiro lugar, as diversas correntes pós-humanistas, incluindo-se o pós-humanismo cibernético, são claramente enaltecedoras da inteligência, da mente, da consciência em prejuízo do corpo (independentemente de que esta abranja um horizonte materialista, reducionista ou ainda metafísico), mantendo firme a convicção sobre sua potencialidade cognitiva cujo desenvolvimento precisa dar-se em sintonia com o arrefecimento dos limites corpóreos. Nesse meandro, assevera Homero Luís A. de Lima (2004, p. 145): “o pós-humanismo cibernético, embora desconstrua o sujeito humanista liberal de várias maneiras, ele, ainda assim, divide com seus predecessores uma ênfase sobre a 'cognição' em detrimento da corporeidade”. E em decorrência disso, afirma Rüdiger (2008, p. 144), “o humano é visto como tendo sua essência na mente, e essa como passível de ser entendida como um sistema de informações encarnado numa virtual máquina". Dessa maneira, a linha de continuidade se confirma pela manutenção da ideia consoante a qual o humano consiste de forma mais própria na inteligência, que deve ser então expandida, otimizada em todo seu potencial, ideia cara à tradição humanista que acreditava atingi-la pelo caminho educativo, moral e religioso, enquanto o projeto pós-humano concebe alcançá-la pela via tecnológica.

Em segundo lugar, e em nítida correspondência com a primeira perspectiva, pode-se conjeturar que o trans ou pós-humanismo almeja realizar em última instância o desideratum humanista de fundo, qual seja, suplantar a animalidade no bumano. Nessa direção, fazemos nossas as palavras de Fabián Ludueña Romandini,

o tão proclamado fim do humanismo e o anúncio da chegada do pós-humanismo resultam, no fundo, um grande equívoco [...]. Todo movimento transhumanista está largamente baseado em um princípio antrópico hostil à animalitas constitutiva do vivente que somos. Os trans-humanistas buscam, na realidade, fabricar pela primeira vez um humano livre de sua animalidade substancial, mesmo que isso implique definir o humano como um simples padrão de informação. Então, sob esta perspectiva, o chamado pós-humanismo é, na realidade, a forma mais sutil e o avatar último do bumanismo (ROMANDINI, 2012, p. 240. Grifo do autor).

Complementando esse raciocínio, o pós-humano reacende entusiástico a chama da eternização: nele há uma luta permanente contra a finitude, contra a morte, como desejo premente de vencê-la em definitivo, que inicia pelas lógicas biotecnológicas de melhoramento (cura para doenças,

de o ser e o não-ser da humanidade depender, a partir de agora, do desenvolvimento da técnica e de sua aplicação"” (NOVAES, 2017, p. 12. Grifo meu). 
remodelação estética, alargamento da juventude, intervenções cirúrgicas, transplantes, próteses, implantes, acoplamentos, substitutivos), e desemboca na transcendência do corpo, este tomado enquanto o que nos prende à morte, recuperando pela ênfase na mente a antiga crença metafísica da alma como aquilo que permanece para além do fenecimento do corpo, nosso transitório e ultrapassado 'biossuporte'.

Aas hipóteses até agora deslindadas acerca do pós-humano podem então ser sintetizadas nos seguintes termos: 1) o pós-humanismo é ao mesmo tempo, de uma perspectiva históricocultural, um movimento e um processo; 2) ele se torna uma realidade como movimento e processo com a expansão da técnica e com ela, a fática e incontornável subjugação humana a um mundo tecnologicamente organizado, administrado e orientado, ganha concreção histórica; e 3) em profundidade, na condição de discurso e propósito, pós-humanismo e humanismo alinham-se por compartilharem a valorização da mente e seu aparato cognitivo em detrimento do corpo, e pretenderem, veementemente, a superação da animalidade no existente humano.

Dito isto, reconhece-se que vivenciamos em diferentes graus e maneiras de experimentação, uma condição, e que esta floresce numa época de transição entre 'dois mundos', um humanista e outro pós-humanista, como coloca Adauto Novaes (2017). Essa condição designando conjuntura, situação ou cenário histórico-cultural - eclode na cotidianidade, adentrando esferas do dia a dia: do trabalho ao lazer, da produção artística à industrial, da comunicação ao preparo das refeições, da consulta médica à luta política, revelando-se igualmente ubíqua no domínio educacional. A conjetura levantada aqui aponta que a experiência do póshumano já é, em boa medida, consciente ou não, precária ou não, desejada ou não, parte significativa do cotidiano escolar e acadêmico. Essa condição que aqui nomeamos condição pósbumana velozmente instaura-se nas vivências hodiernas, e talvez seja justamente nas escolas e universidades, como lugares de formação e produção de saberes por excelência, que "as relações entre informação e conhecimento", como escreve Daniel Figueiredo de Oliveira (2017, p. 23), “devem ser revistas à luz de novas possibilidades de pensar as mediações”; e continua o autor,

ou ainda pelo conjunto de práticas exercidas nos contextos de aprendizagem, seja na escola ou mesmo pelo computador, que envolvem inteligência artificial, sistemas inteligentes e uma nova perspectiva de prática educacional. O mundo e suas formas de expressão não podem mais ser pensados fora de pilares fundamentais da sociedade contemporânea, como a informação, a aprendizagem e o conhecimento, mediados principalmente por novas interfaces, e por uma nova maquinaria.

Por esse ângulo, o pós-humano de algum modo já constitui a realidade escolar porquanto tal realidade arvora-se em microcosmos das sociedades contemporâneas. Ele adentra o espaço escolar e acadêmico, impõe-se sobre as interações sociais instauradas nesses espaços, sobre o fazer 
pedagógico, político-pedagógico e administrativo, condiciona mudanças nas práticas de ensino e aprendizagem, nas relações entre os atores da comunidade escolar (docentes, discentes, funcionários, pais, gestores), na maneira de produção e organização do conhecimento, na estrutura de gestão e governança de secretarias de educação, na legislação educacional e no direcionamento de políticas educacionais.

Por ora, entendo ser possível esmiuçar essa presentificação do pós-humano na educação com base em cinco categorias de análise que perfazem o âmbito educativo formal (não sendo este um quantitativo fechado), podendo figurar na condição de topos epistêmico a futuras investigações filosóficas, sociológicas e pedagógicas. São elas: a estrutura escolar, a prática pedagógica, a formação de professores, o currículo e o cotidiano escolar. Nessa direção, aquela que aparenta ser a mais evidente diz respeito às estruturas escolares: alterações da estrutura física da escola, acesso a computadores, internet, tablets, laboratórios de informática, projetores e lousas digitais, salas e espaços multimídia, elementos que não somente incrementam o sentido contemporâneo de escola, mas que ressignificam o próprio espaço escolar. Tomando em consideração as práticas pedagógicas, categoria de análise que evidencia a dita presentificação, é possível inferir que o usufruto de 'novas interfaces' e 'novas maquinarias' já enformam planejamentos, metodologias de ensino e aprendizagem, recursos metodológicos, procedimentos de avaliação, formas de organização de conteúdos programáticos, entre outros aspectos.

Igualmente, a própria formação de professores no que tange à atualização e apropriação tecnológica (adaptação a tecnologias recentes), à utilização e criação de ferramentas e recursos tecnológicos de ensino e aprendizagem (data gloves, games, redes sociais digitais), ao conhecimento e suporte teórico atualizado sobre novas tecnologias e cibercultura, às formas interacionais e colaborativas de produção de saberes - a novidade do conhecimento produzido em rede, consoante Castells (2008). Além dessas categorias também podem ser mencionadas nesse rol: o currículo, quer como componente curricular (disciplinas de informática, robótica, desenvolvimento de software, desenvolvimento de games, disciplinas ligadas à tecnologia), quer em razão da inevitável tematização e problematização do pós-humano em sala de aula; e o cotidiano escolar, no qual estudantes, professores e comunidade escolar em geral usufruem de gadgets de vários tipos (celulares, smartphones, notebooks, iPods, iPads...), constroem e mantém vivências, relações socioafetivas e formas de conduta mediatizadas por essas ferramentas, mantendo-se frequentemente on line, habitando simultaneamente no modo virtual a realidade e vice-versa, borrando os limites entre esses dois âmbitos, cuja separação é apenas didática e eurística.

Destarte, não seria equivocado afirmar que a ideia subjacente a essas evidenciações, e que começa a estourar no bojo das reflexões filosófico-educacionais, é a ideia de ciborgue, posta por 
estudiosas como Donna J. Haraway (2009, p. 36) em seu Manifesto Ciborgue: Ciência, Tecnologia e Feminismo Socialista no Final do Século XX, nos seguintes termos:

um ciborgue é um organismo cibernético, um híbrido de máquina e organismo, uma criatura de realidade social e também uma criatura de ficção. Realidade social significa relações sociais vividas, significa nossa construção política mais importante, significa uma ficção capaz de mudar o mundo.

Por esse meandro, quatro elementos comporiam o ciborgue reputado como um organismo: o caráter cibernético, a hibridez máquina-organismo, sua condição social e sua qualidade fictícia. Implica dizer que nos tornamos seres com dimensões de interação, comunicação e informação historicamente singulares, entre outras razões, por meio da hiperconectividade, interatividade, do acesso e da apropriação de informação, através dos quais ampliamos possibilidades de controle sobre diversas esferas de atuação humana. Pode-se inclusive assegurar que o mote da hibridização entre humanos e máquinas, do acoplamento entre máquinas e seres humanos, ocorrendo em diferentes níveis (macro e microscópico, nanotecnológico), é um dos pontos altos nas discussões pós-humanistas. Consoante Tomaz Tadeu (2009, p. 10),

uma das características mais notáveis desta nossa era (chamem-na pelo nome que quiserem: a mim, "pós-moderna" não me desagrada) é precisamente a indecente interpenetração, o promíscuo acoplamento, a desavergonhada conjunção entre o humano e a máquina.

Outrossim, o ciborgue - esse presumido anunciador do pós-humano ${ }^{16}$ - vive e se constitui nas relações sociais, sendo produto mesmo destas relações, e em simultâneo, nos termos de Haraway, instaura-se como ficção capaz de transformação da referida realidade.

Tendo em consideração a presença efetiva e irrefreável do ciborgue na cultura, vis a vis seu evidente recrudescimento, expõe-se então uma indagação que vem obtendo musculatura entre tratadistas do fenômeno educativo hodierno, porque fortemente temperada pela referida consideração: o que significa educar quando nos tornamos ciborgues? A esta filiam-se necessariamente outras tantas questões entre aquelas que já batem à porta e aquelas que sequer foram feitas: há lugar para a escola em um futuro pós-humano? E nele, para o exercício da docência? Que mudanças já estão em curso e quais podem se concretizar quanto aos processos de aprender e ensinar? A condição pós-humana repõe a pergunta sobre o significado da formação e o seu para quê? Precisaremos então, como pretende Oliveira (2017), de uma 'pedagogia ciborgue'? Quais os termos de uma educação pós-humanista, uma vez que até antanho predominou uma educação humanista?

\footnotetext{
16 Uma vez mais, nas palavras de Tomaz Tadeu (2009, p. 13), “de um lado, a mecanização e a eletrificação do humano; de outro, a humanização e a subjetivação da máquina. É da combinação desses processos que nasce essa criatura póshumana a que chamamos 'ciborgue"'.
} 
No tocante ao destino das instituições escolares e do moderno processo de escolarização, é conhecida a crítica desferida nos confins do século XX por Ivan Illich em sua talvez prenunciadora obra Sociedade sem Escolas. Nesta o autor sustenta que dentre as instituições modernas, a escola é a responsável pela mais acentuada e sistemática escravização, cuja contradição fundamental reside na suposta e propalada função de formar o espírito crítico dos indivíduos, propondo-lhes que isso se realize por intermédio do estabelecimento da dependência "de um processo pré-empacotado" (ILLICH, 1988, p. 60). Contrário à defesa da conjectura segundo a qual a aprendizagem seria fruto do ensino curricular, Illich (1988) entende que as escolas corromperiam a disposição natural do humano para crescer e aprender, quando esta é transformada em mera exigência de instrução. Em função dessa crítica, o filósofo austríaco enxergava na desescolarização das sociedades contemporâneas ${ }^{17}$, o advento revolucionário da educação e da cultura, e na tecnologia insurgente em sua época, uma alternativa à criação de instituições que incrementariam as interações sociais, de modo criativo e autônomo, fazendo eclodirem novos valores que não pudessem ser controlados pelos tecnocratas. Nessa direção, "é preciso usar a tecnologia moderna", escreve o filósofo, "para tornar a liberdade de expressão, de reunião e imprensa verdadeiramente universal e, portanto, plenamente educativa" (ILLICH, 1988, p. 86).

No pensamento illichiano, a ideia de que a tecnologia pode estar a serviço da autonomia parece ser uma hipótese central. Se se puder admitir enquanto premissa tal hipótese, assumindo igualmente que nos achamos numa curva histórico-cultural ascendente sem precedentes com relação à 'armação' técnica do mundo humano, poder-se-ia interpretar então o ciborgue como uma espécie de abertura a essa possibilidade? Seu acontecimento seria ao mesmo tempo o prenunciador e efetivador desta? Ou em realidade, o que ele anuncia e realiza - num patamar historicamente inequiparável àquele que Illich credita à escola -, é apenas o 'controle tecnocrático' empacotador que o filósofo austríaco queria ver diminuído? Ou ainda, ele poderia significar uma singular transformação cultural que condiciona um denso redimensionamento da educação e da própria instituição escolar?

Tais provocações sinalizam tão-somente tentativas de lançar luzes sobre um fenômeno que por enquanto tateamos. Entretanto, esse 'tatear', reconheçamos, é cada vez mais imperativo, tendo em vista que o pós-humano adentra o currículo, seja ele oculto, indireto ou não, impondose como conteúdo discursivo e programático pelo impacto cultural, moral, religioso de eventos aos quais está visceralmente ligado. E, no limite, pressiona professores, gestores e os próprios estudantes quando se impõe como problema epistemológico, questão social, dilema ético, estético,

\footnotetext{
17 Aqui não cabe, conforme entendemos, promover uma análise sobre a validade da hipótese illichiana da desescolarização das sociedades, posto que tal escopo foge do propósito desse trabalho, podendo ser desenvolvida noutra ocasião.
} 
político ou econômico. Dessa perspectiva, o efetivo acontecer do ciborgue na cultura se coloca como uma tarefa de construção de uma abertura crítica às possibilidades de mudança que já ocorrem e certamente advirão no universo educacional.

\section{Referências}

ASSUMÇÃO, Jéferson. Homem-massa: a filosofia de Ortega y Gasset e sua crítica à cultura massificada. Porto Alegre: Editora Bestiário, 2012.

BERGEL, Salvador Darío. O impacto ético das novas tecnologias de edição genética. Revista Bioética.

CASTELLS, Manuel. A sociedade em rede. 11. ed. São Paulo: Paz e Terra, 2008.

CUPANI, Alberto. Filosofia da tecnologia: um convite. 3. ed. Florianópolis: Editora da UFSC, 2016.

DOUDNA, Jennifer. A.; CHARPENTIER, Emmanuelle. The new frontier of genome engineering with CRISPR-Cas9. Science. Washington: Associação Americana para o Avanço da Ciência, v. 346, no 6213, 2014.

FUKUYAMA, Francis. Nosso futuro pós-humano: consequências da revolução da biotecnologia. Rio de Janeiro: Rocco, 2003.

HABERMAS, Jürgen. O futuro da natureza humana. São Paulo: Martins Fontes, 2010.

IINEK, Martin.; CHYLINSKI, Krzysztof.; FONFARA, Ines.; HAUER, Michael.; DOUDNA, Jennifer. A.; CHARPENTIER, Emmanuelle. A programmable dual-RNA-guided DNA endonuclease in adaptive bacterial immunity. Science. Washington: Associação Americana para o Avanço da Ciência, v. 337, nº 6096, 2012.

ILLICH, Ivan. Sociedade sem escolas. 8. ed. Petrópolis: Vozes, 1988.

LECOURT, Dominique. Humano pós-humano: a técnica e a vida. São Paulo: Loyola, 2005.

LIMA, Homero Luís Alves de. Do corpo-máquina ao corpo-informação: o pós-humano como horizonte biotecnológico. Recife: Pós-Graduação em Sociologia da UFPE, 2004. (Tese de doutorado).

OLIVEIRA, Daniel Figueiredo de. Sobre humanos e máquinas: marcos epistêmicos, ontológicos e éticos para compreensão do ciborgue e aprendizagem humana na cultura digital. João Pessoa: UFPB/PPGE, 2017. (Tese de doutorado).

ORTEGA Y GASSET, José. Meditações sobre a técnica. Lisboa: Sociedade Unipessoal, 2009.

NEVES, Cecília de Sousa. A questão do humano: entre o humanismo e o pós-humanismo. Griot: Revista de Filosofia. Amargosa/BA: UFRB, v. 12, n. 2, dezembro, 2015. 
NIETZSCHE, Friedrich. Assim falou Zaratustra. In: Obras incompletas. 2. ed. Tradução de Rubens Rodrigues Torres Filho. São Paulo: Abril Cultural, 1978. Coleção Os Pensadores.

NOVAES, Adauto (org.). Mutações: entre dois mundos. São Paulo: Edições SESC, 2017.

ROMANDINI, Fabián. A comunidade dos espectros: antropotecnia. Desterro, Florianópolis: Cultura e Barbárie, 2012.

SCHWAB, Klaus. A quarta revolução industrial. São Paulo: Edipro, 2016.

SLOTERDIJK, Peter. Has de cambiar tu vida. Sobre antropotécnica. Valencia: Editorial PreTextos, 2012.

Regras para o parque humano. Uma resposta à carta de Heidegger sobre o humanismo. São Paulo: Estação Liberdade, 2000.

RÜDIGER, Francisco. Cibercultura e pós-humanismo: exercícios de arqueologia e criticismo. Porto Alegre: EDIPUCRS, 2008.

TADEU, Tomaz. Nós ciborgues: o corpo elétrico e a dissolução do humano. In: Antropologia do ciborgue: as vertigens do pós-humano. Belo Horizonte: Autêntica, 2009.

TUNCEL, Yunus (Org.). Nietzsche and transhumanism: precursor or enemy. New Castle: Cambridge Scholars Publishing, 2017. 